\title{
技術報告
}

\section{ヒストグラムインタセクションを用いたクラスタリングによる マルチスペクトル画像の土地被覆分類}

\author{
Land Cover Classification with Multispectral Image \\ by Clustering Method Based on Histogram Intersection
}

\author{
平岡透* ・桃崇 真悟*・越智 達郎*・井上 光平** \\ Toru HIRAOKA, Singo MOMOSAKI, Tatsuro OCHI and Kohei INOUE
}

\begin{abstract}
In this technical report, we propose a new clustering method based on histogram intersection. We prove the effectiveness the proposed method through experiments of land cover classification with multispectral image. Finally, we comment on the respects in which the proposed method is improved and on future prospects.
\end{abstract}

Keywords : ヒストグラムインタセクション, クラスタリング, マルチスペクトル画像, 土地被覆分類

\section{1.はじめに}

クラスタリングは，データ解析方法の一つで，教師 情報を用いずにデー夕を分類する方法である。クラス タリングには多くの方法が提案されており，大きく分 けると, 特定のクラス夕数に分類する分割最適化法と デー夕の分類が階層的になされる階層型法がある。分 割最適化法は予妒決められたクラス夕の数を設定する ことで実行されるが, 階層型法は計算によってクラス 夕数を求めることができる。分割最適化法の代表的な 例として $\mathrm{k}^{-}$平均法やファジィ $\mathrm{C}^{-}$平均法(宮本ら, 1998) などがあり，階層型法の代表的な例として最短距離法 やウォード法, 逐次ファジィクラスタリング(Inoue et al., 1999)などがある。このようなクラスタリングは, 現在様々な分野で活用されており, リモートセンシン グの分野でも土地被覆分類に活用されている(小澤ら， 2001 ; 新井ら, 2002 ; Hiraoka et al., 2003 ; Arai, 2004 ；リモートセンシング研究会編，2004）。

以上のようにクラスタリングには様々な方法が提案 されているが，本技術報告では，ヒストグラムインタ セクション（Yoshimura et al., 2001; 井上ら，2003） を用いた階層型法の新しいクラスタリングを提案す

* 株式会社東京建設コンサルタント環境防災部

**九州大学大学院芸術工学研究院コミュニケーションデザ イン科学部門

「写真測量とリモートセンシング」VOL. 49，NO. 5， 2010
る。ヒストグラムインタセクションは, 辞書データと テストデータの正規化されたヒストグラム間の類似度 をヒストグラムの構成の割合を重視して求める。ヒス トグラムインタセクションの利用としては, 既知の画 像（辞書デー夕）と複数の画像（テストデー夕）の類 似検索や画像内（辞書デー夕）の指定領域と画像内の 類似領域(テストデー夕)の抽出などで, 予め辞書デー 夕が与えられている場合が殆どであり, 辞書デー夕を 自動で抽出するヒストグラムインタセクションを用い たクラスタリングは筆者らの調べる限りではまだな い。

また，本技術報告では，提案法の有効性を検証する ために，まずは簡単なサンプルデー夕を用いて実験を 行い，その後マルチスペクトル画像による土地被覆分 類に応用する。マルチスペクトル画像の各バンドは, 植生やコンクリート, 海, 川などで特徵的な值を持つ ため, マルチスペクトル画像の画素における各バンド をヒストグラムの横軸, 各バンドの值をヒストグラム の縦軸とすれば, 土地被覆による特徽的なヒストグラ ムが作成できる。このとき, 各バンドの值の和が 1 と なるように正規化するため, 各バンドの值の比率に応 じたクラスタリングを行うこととなる。マルチスペク トル画像による土地被覆分類の結果を評価するため に, 国土数值情報 KS-202（1/10細分メッシュ土地利 用）と比較する。

以下， 2 章でヒストグラムインタセクションを用い たクラスタリングとそのマルチスペクトル画像の土地 
被覆分類への適用の方法を説明し，3 章で簡単なサン プルデータ及びマルチスペクトル画像の土地被覆分類 による提案法の実験を行い，4章で本技術報告のまと めと今後の課題，展望について述べる。

\section{2. 方 法}

本章では，まずヒストグラムインタセクションを用 いたクラスタリングの方法を説明し，次に提案法をマ ルチスペクトル画像の土地被覆分類へ適用する方法を 説明する。

\section{1 ヒストグラムインタセクションを用いたクラス タリング}

$I$ 個のデータがあり, 各データのヒストグラムが $J$ 個のビン (区間) からなる場合において， $i$ 番目のデー 夕の $j$ 番目のビンの值を $f_{i, j}$ とする (図 1 参照)。ここ で, ビンの值 $f_{i, j}$ は $\sum_{j=1}^{j=J} f_{i, j}=1$ となるように正規化さ れている。 $i^{\prime}$ 番目と $i^{\prime \prime}$ 番目のデータのヒストグラムイ ンタセクション $s_{i^{\prime}, i^{\prime \prime}}$ を

$S_{i^{\prime}, i^{\prime \prime}}=\sum_{j=1}^{J} \min \left(f_{i^{\prime}, j}, f_{i^{\prime \prime}, j}\right)$

で定義する。ヒストグラムインタセクション $s_{i^{\prime}, i^{\prime \prime}}$ の值 が大きい程, $i^{\prime}$ 番目と $i^{\prime \prime}$ 番目のデー夕が類似している ことを意味する。

$I$ 個のデー夕の中からクラスタの中心を, 式(2)に示 すように，全てのデー夕においてヒストグラムインタ セクションの総和（以下，SHI（Sum of Histogram Intersection）と呼ぶ）が最大となるデー夕とする。

$\max _{i} \sum_{k=1}^{I} s_{i, k}$

まず，第 1 クラスタの中心として，ヒストグラムイ ンタセクション $s_{i^{\prime}, i^{\prime \prime}}$ の $\mathrm{SHI}$ が最大となる $i_{1}$ 番目の デー夕が選ぶ。

次に, 第 2 クラス夕の中心を求める際, $i_{1}$ 番目のデー 夕の影響を取り除くため， $i_{1}$ 番目と $i$ 番目のデー夕の 非類似度 $t_{i}^{(1)}$ を $1-\sum_{j=1}^{J} \min \left(f_{i 1, j}, f_{i, j}\right)$ とし， $i^{\prime}$ 番目と $i$ 番目のデータのヒストグラムインタセクション $S_{i^{\prime}, i^{\prime \prime}}^{(2)}$ を

$S_{i^{\prime}, i^{\prime \prime}}^{(2)}=\sum_{j=1}^{J} \min \left(t_{i^{\prime}}^{(1)} f_{i^{\prime}, j}, t_{i^{\prime \prime}}^{(1)} f_{i^{\prime \prime}, j}\right)$

で求める。第 2 クラス夕の中心は，ヒストグラムイン タセクション $s_{i^{\prime}, i^{\prime \prime}}^{(2)}$ の $\mathrm{SHI}$ が最大となるデー夕 $\left(i_{2}\right.$ 番
目)である。非類似度 $t_{i}^{(1)}$ は， $i_{1}$ 番目と $i$ 番目のデー夕 のヒストグラムインタセクション $s_{i_{1}, i}$ が大きい（類似 している）程，小さな值となる。式(3)において非類似 度 $t_{i}^{(1)}$ をデータの各ビン $j$ の值に掛けることで，第 1 クラスタの中心のデー夕 $i_{1}$ と類似したデー夕 $i$ の ンの值を小さくし，ヒストグラムインタセクション $s_{i_{1}, i}$ を小さくすることで，第 2 クラスタの中心として 第 1 クラスタの中心として既に選ばれたデータ $i_{1}$ と 類似したデー夕 $i$ が選ばれないようにしている。

更に，第 3 クラス夕の中心を求める際， $i_{1}$ 番目と $i_{2}$ 番目のデータの影響を取り除くため, $i_{2}$ 番目と $i$ 番目 のデー夕の非類似度 $t_{i}^{(2)}$ を $1-\sum_{j=1}^{J} \min \left(f_{i_{2}, j}, f_{i, j}\right)$ と し, $i^{\prime}$ 番目と $i^{\prime \prime}$ 番目のデータのヒストグラムインタセ クション $s_{i^{\prime}, i^{\prime \prime}}^{(3)}$

$S_{i^{\prime}, i^{\prime \prime}}^{(3)}=\sum_{j=1}^{J} \min \left(t_{i^{\prime}}^{(1)} t_{i^{\prime}}^{(2)} f_{i^{\prime}, j}, t_{i^{\prime \prime}}^{(1)} t_{i^{\prime \prime}}^{(2)} f_{i^{\prime \prime}, j}\right)$

で求める。第 3 クラスタの中心は，ヒストグラムイン タセクション $s_{i^{\prime}, i^{\prime \prime}}^{(3)}$ の SHI が最大となるデー夕 $\left(i_{3}\right.$ 番 目）である。

同様に，第 $O$ クラスタの中心を求める際， $i_{1}$ 番目か ら $i_{o-1}$ 番目のデー夕の影響を取り除くため, $i_{o-1}$ 番目 と $i$ 番目のデー夕の非類似度 $t_{i}^{(0-1)} 1-\sum_{j=1}^{J}$ $\min \left(f_{i o-1, j}, f_{i, j}\right)$ とし, $i^{\prime}$ 番目と $i^{\prime \prime}$ 番目のデー夕のヒス トグラムインタセクション $s_{i^{\prime}, i^{\prime \prime}}^{(o)}$

$S_{i^{\prime}, i^{\prime \prime}}^{(o)}=\sum_{j=1}^{J} \min \left(\prod_{l=1}^{o-1} t_{i^{\prime}}^{(l)} f_{i^{\prime}, j}, \prod_{l=1}^{o-1} t_{i^{\prime \prime}}^{(l)} f_{i^{\prime \prime}, j}\right)$

で求める。第 0 クラスタの中心は, ヒストグラムイン 夕セクション $S_{i^{\prime}, i^{\prime \prime}}^{(\bar{o})}$ の SHI が最大となるデー夕 $\left(i_{0}\right.$ 番 目）である。

以上の処理を実行すると，クラスタのoの值が大き くなるに従い，SHIは単調に減少し，０に近づく。こ のような既出のクラス夕の中心を取り除く考え方は, 逐次ファジィクラスタリング（Inoue et al., 1999）を 模倣したものである。

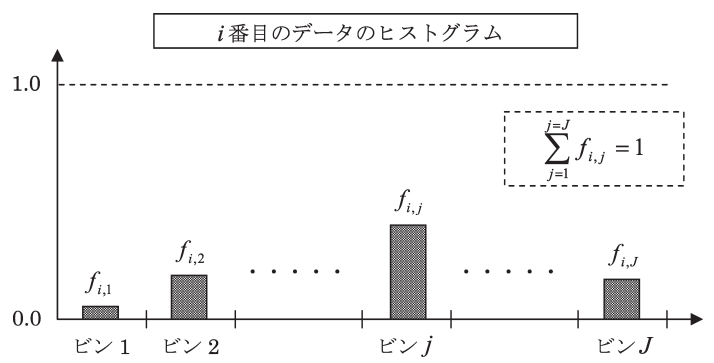

図 1 ヒストグラムの变数の定義 


\section{2 マルチスペクトル画像の土地被覆分類}

画素数が $M$ 個で，バンド数が $N$ 個のマルチスペク トル画像 $G_{m, n}(m=1,2, \ldots, M ; n=1,2, \ldots, N)$ に対し て，土地被覆分類を行う。まず，マルチスペクトル画 像の各画素における各バンドの值 $G_{m, n}$ の和が 1 とな るように正規化し, 正規化後の值を $g_{m, n}$ とする (式(6)参 照)。

$g_{m, n}=\frac{G_{m, n}}{\sum_{n=1}^{N} G_{m, n}}$

正規化後の值 $g_{i, j}$ を2.1節の $f_{i, j}$ とすること（図 2 参 照)でクラスタリングを行い, SHIが $T$ 以上のクラス 夕の中心を抽出する。ここで，T に近い值を設定すれば良い。または，Tの変化を見て 判断しても良い。以下の実験では，Tの大きさと変化 を見て，人がクラスタの数を決定した。これによって 得られたクラス夕数を $U$ 個とし，クラスタの中心を $C_{u}(u=1,2, \ldots, U)$ とする。

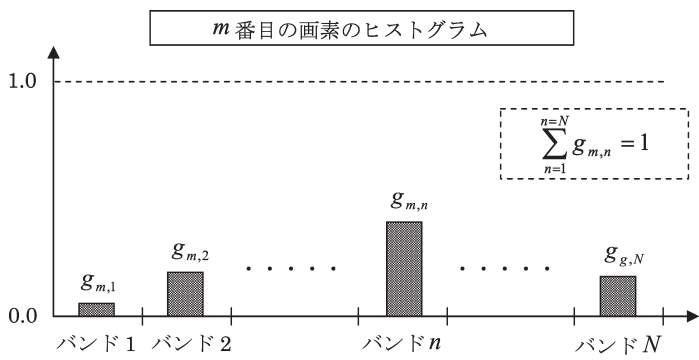

図 2 マルチスペクトル画像の変数の定義

最後に, マルチスペクトル画像の各画素 $g_{m, n}$ と各ク ラスタの中心 $C_{u}$ とのヒストグラムインタセクション を求め, マルチスペクトル画像の各画素 $g_{m, n}$ を最も七 ストグラムインタセクションが大きくなるクラスタに 分類する。

\section{3. 実 験}

本章では，提案法の有効性を検証するために，まず
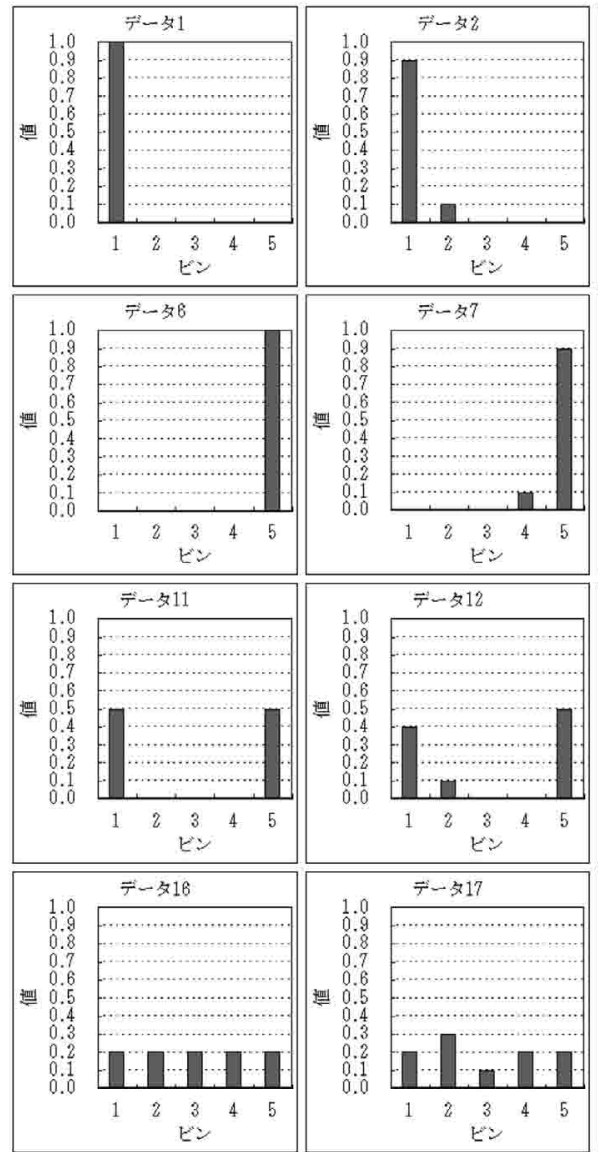

図 3 サンプルデータ
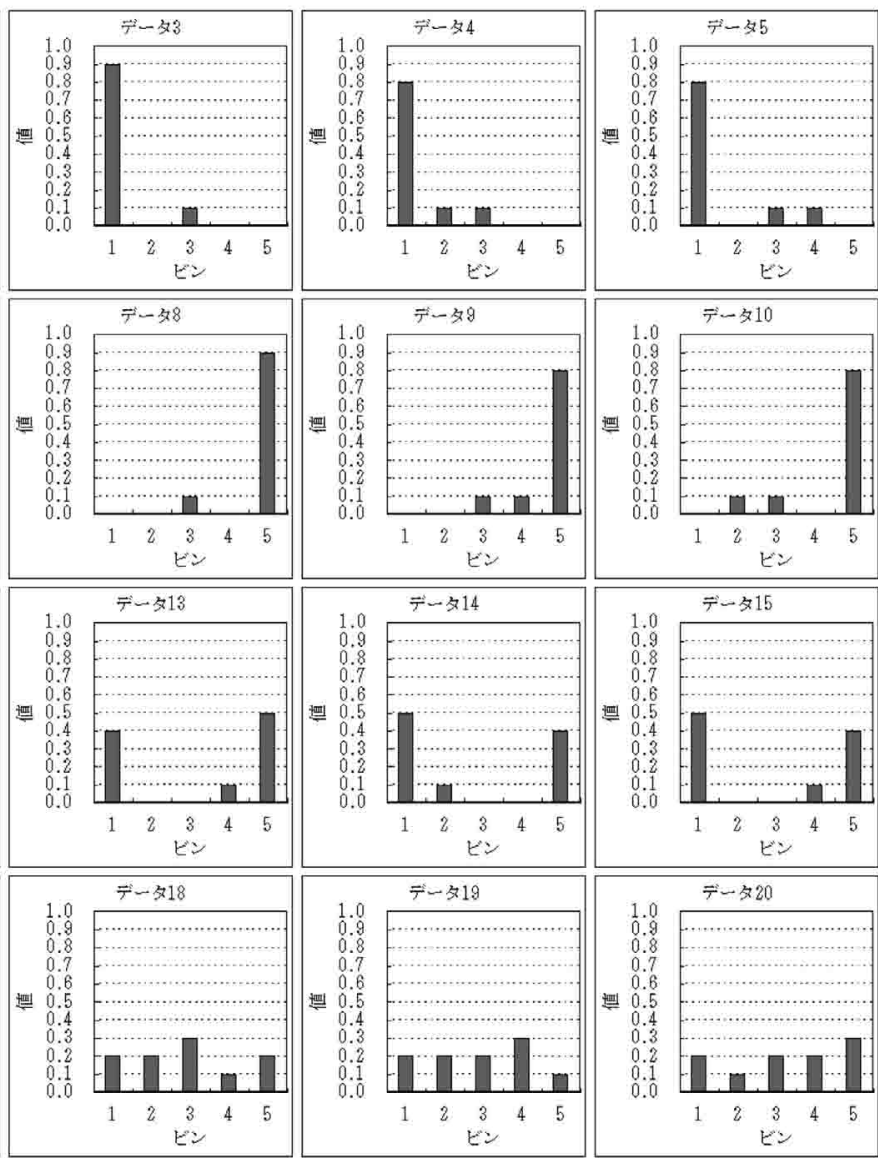
簡単なサンプルデータを用いて実験を行い，次にマル チスペクトル画像の土地被覆分類による実験を行う。

\section{1 サンプルデータを用いた実験}

提案法を困 3 に示すデー夕 1 からデー夕 20 までの 20 個のサンプルデータ（ビン数 5 ) に適用した。サンプ ルデータは, データ 1 からデータ 5 がクラス 1 , デー 夕 6 からデータ 10 がクス 2 , データ 11 からデー夕 15 がクラス 3 , データ 16 からデー夕 20 がクラス 4 となる 4 つのクラスに分類できるように設定している。

提案法を用いて順次抽出された各クラスタのデータ 名, クラス名, クラスタ中心の SHI, SHI の変化量を 表 1 に示す。表 1 より，4 番目のクラス夕まで求めれ ば，4つクラスからクラスタの中心がそれぞれ抽出さ

表 1 提案法を用いて順次抽出されたクラスタの緒言

\begin{tabular}{|c|c|c|r|r|}
\hline $\begin{array}{c}\text { クラスタ } \\
\text { ナンバー }\end{array}$ & データ名 & クラス名 & $\begin{array}{c}\text { クラスタ } \\
\text { 中心の SHI }\end{array}$ & $\begin{array}{c}\text { SHI の } \\
\text { 変化量 }\end{array}$ \\
\hline \hline 1 & データ 13 & クラス 3 & 10.800 & 6.950 \\
\hline 2 & データ 16 & クラス 4 & 3.850 & 2.206 \\
\hline 3 & データ 3 & クラス 1 & 1.644 & 0.550 \\
\hline 4 & データ 8 & クラス 2 & 1.094 & 0.885 \\
\hline 5 & データ 14 & クラス 3 & 0.209 & 0.136 \\
\hline 6 & データ 19 & クラス 4 & 0.073 & 0.041 \\
\hline 7 & データ 7 & クラス 2 & 0.032 & 0.006 \\
\hline 8 & データ 2 & クラス 1 & 0.026 & - \\
\hline
\end{tabular}

※SHI の変化量は, 注目しているクラスタ中心の SHI か ら次のクラスタ中心の SHI を引いた值である。
れていることが分かる。また，クラス夕を順次抽出す るに従い, SHIも単調に減少していることも確認で き，更に SHI がある程度の大きさを持ち，変化量が小 さくなるのは，4 番目のクラス夕までであることが分 かる。以上より, 提案法の基本的な処理を通して, 良 好なクラスタリングが行えることが確認できた。

\section{2 マルチスペクトル画像の土地被覆分類の実験}

提案法を 2 次メッシュコード503023 (福岡南部) の 約 $10 \times 10 \mathrm{~km} の$ 範囲の LANDSAT-TM 画像（2004年 4 月撮影, $338 \times 300$ pixl, バンド数 7 , 階調数 255 , 地 上分解能約 $30 \mathrm{~m})$ に適用した。この範囲には, 河川や湖 沼, 市街地, 宅地, 森林などの土地被覆が存在する。 実験で使用したLANDSAT-TM の 7 つのバンドの 画像を図 4 に, 2 次メッシュコード503023の地形図(国 土地理院2004年 4 月刊行の数值地困25000) を困 5 に示 于。

提案法を用いて順次抽出された各クラス夕中心の SHI, SHI の変化量, 各バンドの画素值を表 2 に示す。 表 2 より，第 4 クラス夕までSHI 及び SHI の変化量 がある程度大きな值を持っているため，第 4 クラス夕 までのクラスタの中心を用いて土地被覆分類を行っ た。土地被覆分類の結果を図 6 に示す。図 6 において, 分類された画素をクラス夕 1 は黄色, クラス夕 2 は青 色, クラス夕 3 は緑色, クラス夕 4 は赤色で表現して いる。図 6 の土地被覆分類の結果と図 5 の地形図を比 較すると, クラス夕 1 は建物密度が疎な地域, クラス 夕 2 は水部, クラス夕 3 は森林部, クラス夕 4 は建物

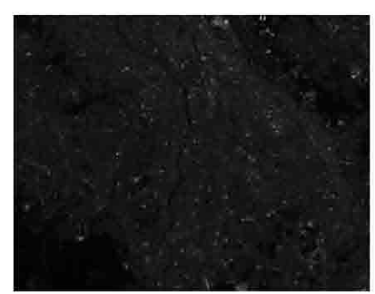

バンド 1

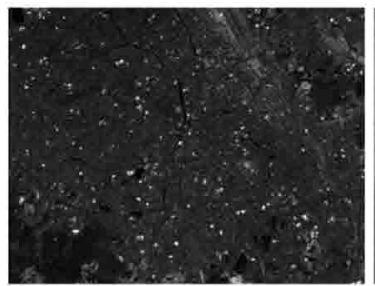

バンド 5

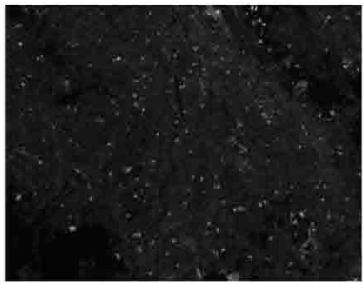

バンド 2

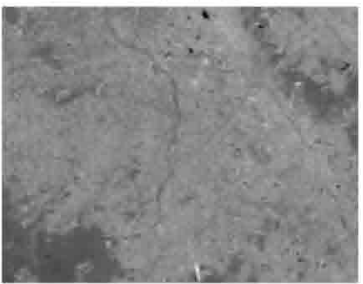

バンド 6

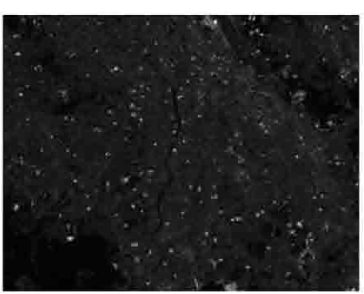

バンド 3

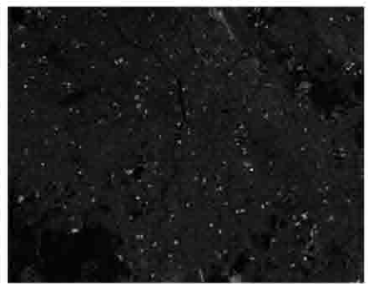

バンド 7

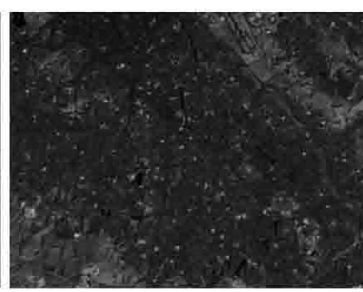

バンド 4

図 4 実験で使用した LANDSAT-TM 画像 
表 2 提案法を用いて順次抽出されたクラスタの緒元

\begin{tabular}{|c|c|c|c|c|c|c|c|c|c|}
\hline \multirow{2}{*}{$\begin{array}{l}\text { クラスタ } \\
\text { ナンバー }\end{array}$} & \multirow{2}{*}{$\begin{array}{c}\text { クラスタ } \\
\text { 中心の SHI }\end{array}$} & \multirow{2}{*}{$\begin{array}{l}\mathrm{SHI} の \\
\text { 変化量 }\end{array}$} & \multicolumn{7}{|c|}{ 各バンドの画素值 } \\
\hline & & & 1 & 2 & 3 & 4 & 5 & 6 & 7 \\
\hline 1 & 97965.717 & 81253.239 & 30 & 33 & 36 & 46 & 49 & 167 & 33 \\
\hline 2 & 16712.478 & 11712.147 & 19 & 20 & 22 & 41 & 33 & 159 & 19 \\
\hline 3 & 5540.331 & 3384.224 & 4 & 6 & 5 & 70 & 22 & 115 & 7 \\
\hline 4 & 2156.107 & 1568.869 & 57 & 53 & 62 & 48 & 43 & 156 & 29 \\
\hline 5 & 587.238 & 278.249 & 33 & 44 & 40 & 10 & 7 & 141 & 3 \\
\hline 6 & 308.998 & 190.846 & 12 & 19 & 16 & 147 & 59 & 146 & 19 \\
\hline 7 & 118.152 & 75.329 & 7 & 9 & 7 & 85 & 69 & 104 & 33 \\
\hline 8 & 42.823 & - & 17 & 19 & 13 & 4 & 3 & 137 & 1 \\
\hline
\end{tabular}

※SHI の変化量は, 注目しているクラスタ中心の SHI から次のクラスタ中心の SHI を引いた值である。

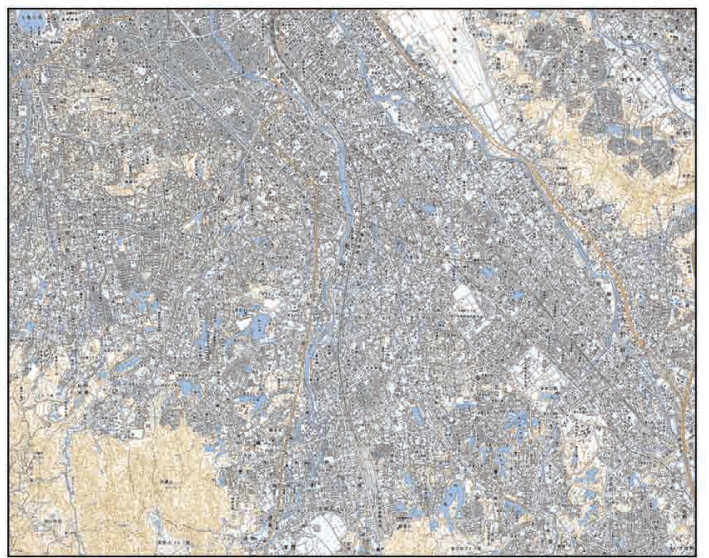

図 5 LANDSAT-TM 画像の範囲の地形図(国土地理院発 行の数値地図25000)

密度が密な地域を表していると推測できる。

また，土地被覆分類の結果を定量的に判断するため に，国土数值情報 KS-202 (平成18年 (2006年) 土地利 用メッシュ）を用いて，マルチスペクトル画像の画素 の中心に最も近い土地利用メッシュの中心を対応付け ることで比較検証を行った。土地被覆分類の結果と比 較の対象とした土地利用メッシュの範囲を図 7 に示 す。土地利用メッシュは，10m 間隔のメッシュで構成 され，12種類の属性（田，その他の農用地，森林，荒 地，建物用地，幹線交通用地，その他の用地，河川地 及び湖沼，海浜，海水，ゴルフ場，解析範囲外)を持っ ている。そこで，土地被覆分類の結果と土地利用メッ シュの属性が表 3 に示寸組み合わせにおいて正解の対 応付けが行われたとして，土地被覆分類の結果得られ たクラス夕 1 からクラス夕 4 までの正解率を求めた。

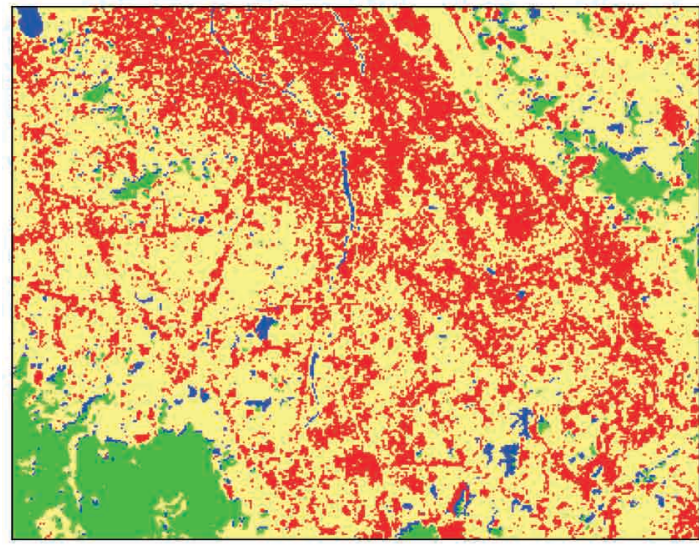

図 6 提案法を用いた土地被覆分類

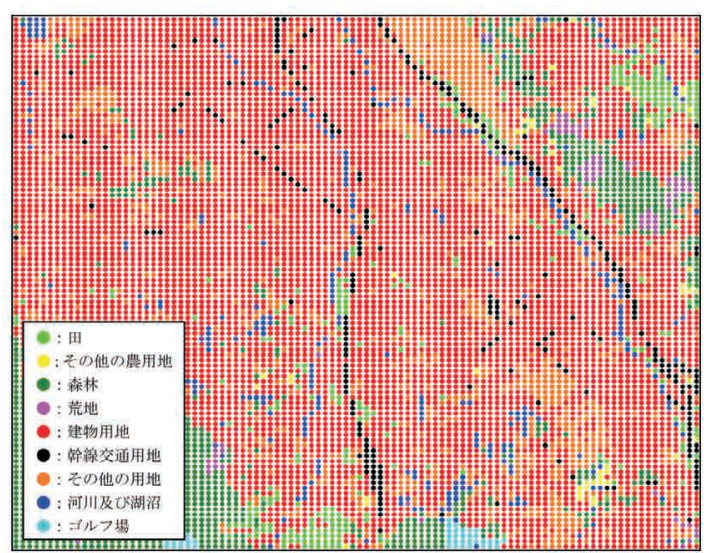

図 7 国土数值情報 KS-202（平成18年（2006年）土地利用 メッシュ)

正解率は, 各クラス夕において, 全画素数における正 解の画素数の割合である。各クラス夕の正解率を表 4 
表 3 土地被覆分類の結果と土地利用メッシュの属性の対 応付け

\begin{tabular}{|c|c|c|}
\hline $\begin{array}{c}\text { クラスタ } \\
\text { ナンバー }\end{array}$ & $\begin{array}{c}\text { 推測される } \\
\text { 土地被覆 }\end{array}$ & $\begin{array}{c}\text { 対応付けられる } \\
\text { 土地利用メッシュの属性 }\end{array}$ \\
\hline \hline 1 & $\begin{array}{c}\text { 建物密度が } \\
\text { 疎な地域 }\end{array}$ & $\begin{array}{c}\text { 田, その他の農用地, 荒地, } \\
\text { 建物用地, 幹線交通用地, } \\
\text { その他の用地 }\end{array}$ \\
\hline 2 & 水部 & 河川地及び湖沼 \\
\hline 3 & 森林部 & 森林 \\
\hline 4 & $\begin{array}{c}\text { 建物密度が } \\
\text { 密な地域 }\end{array}$ & $\begin{array}{c}\text { 建物用地, 幹線交通用地, } \\
\text { その他の用地 }\end{array}$ \\
\hline
\end{tabular}

表 4 土地被覆分類の結果と土地利用メッシュの 属性との関係

\begin{tabular}{|c|c|r|}
\hline $\begin{array}{c}\text { クラスタ } \\
\text { ナンバー }\end{array}$ & 推測される土地被覆 & 正解率 $[\%]$ \\
\hline \hline 1 & 建物密度が疎な地域 & 88.553 \\
\hline 2 & 水部 & 59.313 \\
\hline 3 & 森林部 & 80.215 \\
\hline 4 & 建物密度が密な地域 & 89.763 \\
\hline
\end{tabular}

に示す。土地被覆分類の結果において水部と推測され るクラスタ以外は土地利用メッシュの属性との対応付 けが $80 \%$ 以上で行われたことから，比較的良好な結果 が得られたと判断した。

\section{4.おわりに}

ヒストグラムインタセクションを用いた新しいクラ スタリングを提案し，まずは簡単なサンプルデー夕を 用いた実験により提案法の動作確認を行い，その後マ ルチスペクトル画像による土地被覆分類の実験を行う ことで，提案法の有効性を検証した。提案法は, サン プルデータのみでなく，マルチスペクトル画像の土地 被覆分類においても比較的良好な結果が得られると評 価する。今後の課題は, クラス夕数を自動で決定する 基準を確立することと,より多くの場所で実験を行い, 検証を重ね，提案法の性能を向上させることと，提案 法は現在全探索で処理を実行しているため, 提案法の 処理の削減を図ることである。また，本クラスタリン グは，マルチスペクトル画像の土地被覆分類以外にも 様々な分野でも応用できると考之るため, 多くの分野 で活用することも今後の課題である。

（受付日2010.4.7，受理日2010.9.15）

\section{参考文献}

新納浩幸, 2007. R で学ぶクラス夕解析, オーム社, 東京.

Kohei Inoue and Kiichi Urahama, 1999. Sequential fuzzy cluster extraction by a graph spectral method, Pattern Recognition Letters., Vol. 20, No. 7, pp.699-705, 1999.

宮本定明, 馬屋原一孝, 向殿政男, 1998. ファジィ $\mathrm{C}^{-}$平 均法とエントロピー正則化における分類関数, 日本 ファジィ学会誌, Vol. 10, No. 3, pp.548-557.

宮本定明，1999。 クラスター分析入門ーファジィクラ スタリングの理論と応用，森北出版，東京. 小澤憲秋，青木俊徳，加藤 寧，根元義章，2001．局 所領域でのクラスタリングによる衛星画像の雲域自 動分類, 電子情報通信学会論文誌, Vol. J84-D2, No. 8, pp.1608-1617.

新井康平, 芳沢 聡, 建野耕一, 2002. 衛星画像クラ スタリングへの Messy 遺伝アルゴリズムの適用, 写 真測量とリモートセンシング, Vol. 41, No. 5, pp. 37-41.

Toru Hiraoka, Kohei Inoue and Kiichi Urahama, 2003. Data reduction by sample clustering for Fuzzy Segmentation of Multispectral, International Workshop on Advanced Image Technology 2003, pp.55-60.

Kohei Arai, 2004. Learning processes of image clustering method with density maps derived form Self-Organizing Mapping (SOM), 写真測量とリ モートセンシング, Vol. 43, No. 5, pp.62-67.

Kohei Arai, 2004. Non-linear merge and split method for image clustering, 写真測量とリモート センシング, Vol. 43, No. 5, pp.68-73.

リモートセンシング研究会編, 2004. 改訂版図解リモー トセンシング, 社団法人日本測量協会, 東京.

Tetsuya Yoshimura, Tadashi Ichikawa, Shigeo Morishima and Kiyoharu Aizawa, Takahiro Saito, 2001. A Human Face Tracking Using Color Histogram Intersection Matching Method, 映像 情報メディア学会誌, Vol. 55, No. 3, pp.412-416. 井上光平, 浦浜喜一, 2003. ヒストグラムインタセク ションの上限と下限に基づくフィルタリング検索, 電子情報通信学会論文誌, Vol. J86-D2, No. 2, pp. 358-370. 